\title{
article a place under SIEGE: self-censorship strategies among Cuban state media journalists
}

Copyright $\odot 2019$ SBPjor / Associação Brasileira de Pesquisadores em Jornalismo
ANNE NATVIG

Høgskulen i Volda, Volda, Møre og Romsdal - Norway

University of Oslo, Oslo - Norway

DOI: $10.25200 /$ BJR.v15n2.2019.1236

Received on: 16/01/2019 | Approved on: 20/04/2019

\begin{abstract}
This article analyses how enemy images of the US in Cuba affect journalists in the Cuban state media. For the political elite, the image of US imperialistic interests has legitimated their continuing control over the media. Within these limits, journalists negotiate between professional ideals and a responsibility to protect the country. Journalists accept self-censorship of stories that, in theory, damage Cuban interests. At the same time, journalists see the US threat as inflated, and worry about the lack of relevant information available to the public. While journalists oppose censorship and self-censorship on everyday issues, attempts to change these practices are confined to theoretical discussions.

Key words: Authoritarian regime. Cuban journalism. Enemy images. Self-censorship.
\end{abstract} State media.

\section{UM LUGAR SITIADO: estratégias de autocensura entre jornalistas do Estado cubano}

RESUMO - Este artigo analisa o modo como imagens hostis aos Estados Unidos em Cuba afetam os jornalistas dos meios de comunicação estatais cubanos. Para a elite política, a imagem dos interesses imperialistas dos Estados Unidos vem legitimar o seu controle permanente sobre os meios de comunicação. Com estas limitações, os jornalistas se veem obrigados a equilibrar os ideais profissionais com a sua responsabilidade de proteger a nação. Os jornalistas aceitam se autocensurar em matérias que, teoricamente, prejudicam os interesses cubanos. Ao mesmo tempo, os jornalistas consideram a ameaça norte-americana como sendo deliberadamente exagerada e preocupam-se com a falta de informação relevante que se encontra disponível ao público. Enquanto os jornalistas se confrontam com censura e autocensura em assuntos do quotidiano, as tentativas de mudar essas práticas estão confinadas às discussões teóricas.

Palavras-chave: Regime autoritário. Jornalismo cubano. Imagens hostis. Autocensura. Meios de comunicação estatais. 


\section{PLAZA SITIADA: estrategias de autocensura entre periodistas en medios del Estado cubano}

RESUMEN - Este artículo analiza el modo en que las imágenes de EE.UU. como enemigo de Cuba afectan a los periodistas de los medios de comunicaciones cubanos. Para la élite política, la imagen de los intereses imperialistas de EE.UU. ha contribuido a legitimar su control continuo de la prensa. Actuando dentro de esos límites, los periodistas se ven obligados a equilibrar sus ideales profesionales con la responsabilidad de proteger a su país. Los periodistas aceptan la autocensura en cuanto a noticias que en teoría puedan perjudicar los intereses cubanos. A la vez, los periodistas consideran que se exagera con respecto a la amenaza norteamericana, y se preocupan por la falta de acceso por parte del pueblo a información relevante. Los periodistas se oponen a la censura y la autocensura en los asuntos cotidianos, pero los esfuerzos aplicados a cambiar estas prácticas se limitan a debates teóricos.

Palabras clave: Régimen autoritario. Periodismo cubano. Narrativas de enemigo. Autocensura. Prensa estatal.

\section{Introduction}

The antagonism between Cuba and the United States is well documented; media outlets worldwide publish disagreements between the countries. What is less often researched is how the difficult relationship affects the work of journalists in the Cuban state media. The threat of the US undermining or changing the Cuban social and political system causes journalists to apply various strategies of self-censorship to protect their nation.

Hitherto, there has been little research on journalistic strategies and the justifications for self-censorship in Cuba. Although this phenomenon is often referred to in reports on press freedom by organisations such as Freedom House or Reporters Without Borders, academic studies seldom make self-censorship the main focus of research. This article aims to contribute towards deepening knowledge of the specific journalistic processes (rather than political and juridical frameworks) leading to self-censorship. Through narratives from respondents, the article discusses the following research questions: 
1. How do perceptions of a US threat contribute to selfcensorship in the Cuban state media?

2. To what extent are signs of changing self-censorship practices among Cuban journalists evident?

\section{A brief history of Cuban media}

The relationship between Cuba and the US is documented in Cuban media history, both before and after the 1959 revolution. The geographical and historical proximity of Cuba and the US, as well as the increasing ideological divide between the countries, are important aspects for an understanding of how the perceived threat from the US affects journalists in Cuba today.

Before the revolution, Cuba had been a testing ground for US radio and television broadcasting, so the technology used in Cuba at the time was ahead of that of most comparable countries. In the 1950s, there were more than 150 local and national radio stations in Cuba, and six television channels (García Luis, 2013, p. 75). A majority of these were owned and run by US companies, financed by advertising. However, it was possible to find a variety of Cuban voices in newspapers and magazines (Marrero, 2003, p. 58). The development of television in Cuba followed rapid and unexpected transformations in the Cuban nation-state. Some scholars view Cuba before the Batista military coup of 1952 as a democracy in which the media had a relatively strong degree of political influence and a plurality of expression (Guerra, 2012; Rivero, 2015). During the Batista dictatorship, the broadcasting system detached itself from US capitalist principles and censorship became widespread: this situation lasted until the revolution of 1959.

Cuban media scholars see the five years after the revolution as a golden age for the media (Garcés, 2012; García Luis, 2013). Cuban journalism had severed its ties with the market-driven US model and had still not been influenced by the bureaucratic Soviet model (Siebert et al., 1984). A new, socialist press was to be developed. However, defining events in Cuba-US relations, such as the Bay of Pigs invasion in 1961, and the 1962 Missile Crisis, moved Cuba closer to the USSR - with lasting consequences for the media.

It is uncertain whether the revolutionary government intended to nationalise the media after the revolution. García Santamaría (2017, 
p. 47) considers that nationalisation of the media may have come about as a result of anti-Batista zeal, the exodus of journalists and editors, and pressure from unionised media workers. In 1965, the Cuban Communist Party (PCC) was founded and aligned the press with politics - which according to García Luis (2013, p. 81), led to major setbacks in journalistic content and creativity, and the media's loss of authority to make their own decisions. In addition, the older generation, which had worked under capitalism, was replaced with a new one, bringing changes in the coverage of themes, genres and style. The threat of a possible US invasion prompted the consolidation of political power and spurred a press system designed to block counterrevolutionary strategies (p. 85).

The commercial, economic and financial embargo imposed by the US on Cuba (referred to in Cuba as el bloqueo, the blockade) has contributed to the continuing difficulties in Cuba-US relations. It has also nurtured conservative forces within Cuba that wish to perpetuate the notion of the US as an enemy, with the belief that any policy concessions to the US will weaken Cuba (Hernández, 2003, p. 110). The contradictory process of the Cuban public's contribution towards the creation of a state that proceeded to severely limit their agency, can be explained through the political construction of a master narrative of unity and resistance. The dismantling of US economic and cultural hegemony, as well as a cleansing from the indignity and injustices of past governments, required the media's unconditional support and selfsacrifice. This implied acceptance of mass organisation as a substitute for a public sphere with individual agendas - a narrative which inscribed the Cuban people as protagonists in an interminable battle between freedom and imperialism, good and evil (Guerra, 2012, p. 5).

The influential Cuban academic and journalist Julio García Luis (2013, p. 116) recalls Cuban journalism in the 1970: '...almost without noticing we had started making a press to please the system rather than serve public opinion'. In the next decade, various congresses of the PCC and the Union of Cuban Journalists (UPEC) declared that journalism should be objective, true and analytical, and that the apologetic style of the press would have to change (Marrero, 2006, p. 56). Finally, the 1986 UPEC Congress managed to start a process of press reform. Fidel Castro was present at the congress and declared: 'No enemy will critique us better than we do ourselves' (Marrero, 2006, p. 73). But just a few years later the Soviet Union collapsed. Resisting foreign threats became the priority of the PCC, and an authoritarian attitude towards 
the press replaced calls for criticism. Since 2000, online media outlets and bloggers have increasingly challenged the informational role of the state press. Cuba still ranks as 172 out of 180 countries on the Press Freedom Index of Reporters Without Borders (2018).

A policy regulating the press has been in the making since 2013, and in 2018 it was finally presented. The document acknowledges several difficulties, such as external control of the press, the withholding of information, self-censorship and a deteriorating professional culture (PCC, 2018, p. 6). However, as the non-state platform Periodismo de Barrio points out, the document does not suggest action in respect of the main source of these issues, namely the PCC whose functionaries were part of the working group formulating this policy. Further, state media expected to be almost 'schizophrenic', as they are told to be independent of the party (Periodismo de Barrio, 2018). At the same time, the communication policy document states that the PCC is 'the director of social communication in the country, draws up the general policy for its development and controls it' (PCC, 2018, p. 10).

Following this, president Miguel Díaz-Canel held a closing speech at the Cuban Journalists Union (UPEC) where he praised state media journalists for resisting joining well paid but 'opportunist and cynical' campaigns against Cuba [referring to offers from Miami media outlets]. Díaz-Canel said the media scene never before has been as challenging, but he made sure to remind journalists of the hardships Cuba had been through previously. Citing Fidel Castro, Díaz-Canel considered that: 'the central role of journalism [is] in defending the besieged fortress' (Granma, 2018).

This notion is a reference to Cuba's being under constant attack by the US and it is referred to by participants as the concept of plaza sitiada. State media journalists use this concept to explain or dispute (self-)censorship on subjects that can be spun by US media, referring in particular to outlets in Miami. Hernández (2003, p. 110) maintains that 'the consequent mentality of a fortress under attack does not contribute to pluralism in Cuba'. That Díaz-Canel made the effort to mention this concept, point towards a hardening of the relation between the countries. The Cuban president's activities on Twitter support this. For instance, in commemorating the Bay of Pigs he claims that the US continues with 'the same lies and aggressions' and Cuba with 'equal courage and fidelity' (Díaz-Canel, 2019). Such rhetoric from the leadership of the PCC may consequently mean a hardening of media policy. 


\section{Processes of self-censorship}

Self-censorship is a practice found in journalistic cultures around the world, but it is a difficult phenomenon to define. There can be informal processes of self-censorship: referring to journalistic reporting practices when selecting stories, routines in the newsroom or cultural expectations. Self-censorship can also be more formal: it can be guided by institutionalised expectations of journalistic behaviour, or practices to avoid punishment or threats from public authorities (Elbaz et al., 2017; Lee, 1998; Skjerdal, 2010). The approach of this article is closer to a formal understanding of selfcensorship, and will depart from Skjerdal's (2010, p. 99) definition of self-censorship as 'the withholding of journalistic material due to felt external pressure'.

Self-censorship practices are, in many ways, conditioned by the media system in the country, and depend on the degree to which media structures favour or restrict dissenting opinions (Elbaz et al., 2017). For this article it therefore makes sense to limit the review to countries with a somewhat similar state media system as Cuba's, rather than to countries that are geographically close by. Although self-censorship is found in Latin America, state media in the region are generally more challenged by private media than is the case in Cuba - although it should be noted that populism in Ecuador, Venezuela and Bolivia has brought about tighter control of or expropriation of private media (Waisbord, 2012, p. 508). Little research has, however, been done on how journalists experience these changes. There is an overall need for more research on how journalists apply and narrate self-censorship practices, which Skjerdal (2010, p. 98) also notes. This article attempts to contribute to knowledge of how journalists in authoritarian countries experience and relate to self-censorship, as well as filling some of the gaps in the research on Latin American journalism in general, and on Cuba in particular.

In societies with a long tradition of authoritarian rule, a tendency towards burying sensitive information - especially information critical of the governing party - can be the norm for journalistic behaviour. This is a consequence of the media not having a 'watchdog' role in society, combined with journalists' lack of faith in declarations of freedom of speech. This, in turn, promotes selfcensorship strategies among journalists. Some contributing factors are punishment and rewards by ruling elites (Elbaz et al., 2017, p. 
128). Following the Chinese takeover of Hong Kong, Lee (1998, p. 58) maintains that self-censorship among Hong Kong journalists arose as a result of a lack of better alternatives in facing China's power to reprimand or to reward journalistic coverage. This continues today in China, where fines, arrests, demotions and libel lawsuits induce journalists to self-censor (Xu, 2014). The fear of consequences similarly stimulated self-censorship in South Africa during apartheid, and in Indonesia during the New Order regime, and are practices continuing despite transition from authoritarian rule (Merrett, 2001; Tapsell, 2012). In Russia, after a wave of terrorist attacks from 1999 onwards, journalists agreed to draw up 'responsible' guidelines for the coverage of terrorism, something Simons and Strovsky (2006, p. 205) consider a trade-off for harsher media laws, and a way to preclude media outlets from fines and closedowns.

Other aspects promoting self-censorship are the individual's commitment to social, ideological or political beliefs (Elbaz et al., 2017, p. 131). Skjerdal (2010, p. 116) contends that journalists in Ethiopia justify self-censorship by disclaiming their own role in the state media system while at the same time committing to the governmental strategy of development journalism, thereby withholding information that could harm the country or its citizens. Furthermore, uniting over a common enemy is something that can promote self-censorship in times of conflict, a tendency seen in authoritarian as well as democratic countries: in the US following the invasion of Iraq in 2003; in Russia after the 1999 terrorist attacks; and in Israel after the second intifada (Nohrstedt \& Ottosen, 2001; Simons \& Strovsky, 2006; Zandberg \& Neiger, 2005).

\section{Enemy images}

For Cuban journalists there is an external variable that must always be taken into account: current relations with the US. The risk of a 'capitalist domination and subversion of the Cuban social order' brings constant tension to Cuban journalism (Alonso \& Pérez, 2016, p. 199). Theoretical perspectives on the creation and preservation of enemy images can contribute towards understanding how Cuban journalists, as producers of these, are affected in their work situation.

Luostarinen (1989, pp. 124-127) claims that the relationship between countries, but also the internal affairs within them, affect the 
processes of developing enemy images. He defines enemy images as 'a belief held by a certain group that its security and basic values are directly and seriously threatened by some other group'. Enemy images always involve the possibility of violence and destruction; they are not merely feelings of antipathy. In countries where there is a permanent state of conflict or war, the state must always be prepared, not only militarily and economically, but also culturally. The preservation of enemy images is part of the defence - 'mental drills' in preparation for war. Adding a perspective of time serves to enhance the image: the enemy may be an arch-enemy of the past, but it is also a threat to a common future. There are several advantages to enemy images: they may integrate groups, diminish internal conflict, and strengthen national identity (Luostarinen, 1989, p. 127).

Images of an enemy can be constructed in various ways. Ottosen (2004, p. 218) draws a distinction between situational and dispositional enemy images. A situational enemy image involves a description of one specific incident of hostility. If, over time, there are many such incidents, a dispositional enemy image may develop, and aggressive behaviour will be expected from the enemy. Dispositional enemy images are difficult to change, as they are composed of stereotypes internalised in language and culture. These are reflected in the media through standardised characteristics of the enemy, even if journalists do not deliberately decide to do this.

\section{Methodology}

My data consists of 12 semi-structured qualitative interviews with journalists in the Cuban state media. By state media I refer to news outlets paid for either by the Cuban government or through the state budget. The interviews were conducted during a two-month fieldwork trip in the autumn of 2016 . Anonymity for participants is important in the Cuban context. The journalists interviewed work in state newspapers and in broadcasting, their titles ranging from editors to recent graduates. The names of both workplaces and positions have been omitted from this article. Instead, I divide the journalists into three age groups, and give them pseudonyms. There were five in the group young reporter (20-34 years), five middle-aged reporters (35-49 years), and two senior reporters (50+ years). The participants chose where they wanted the interview to take place, 
and I met most of them outside the workplace. The interviews were recorded if participants agreed to it, which everyone did.

I had a contact at the Faculty of Communications (FCOM) at the University of Havana and was allowed to use their internet and intranet to obtain research from the faculty. My contact advised me to get a research visa. A foreign researcher interviewing state journalists with a tourist visa was considered something that could cause trouble both for me and the FCOM. However, getting the visa was difficult. While waiting for the visa, I created a list in collaboration with my contact, primarily with journalists I found interesting. As a scholar of journalism, my contact has a broad overview of Cuban journalists, and I found his contributions to this list very valuable, and the opposite of restraint on my research. Gaining access to state media journalists would have been much more difficult without this contact. He helped me obtain telephone numbers and navigate the intricate system of getting in touch in a society that is largely offline, and which has extremely expensive mobile costs compared to state salaries.

I used an interview guide inspired by the questionnaire in the Worlds of Journalism study (WoJ, 2012). It dealt with professional roles and values, construction of news, daily routines, internet and social media. For the purposes of this article, important questions were: Who decides which stories should be prioritised?; Are there subjects one should not write about?; and How do you select your sources? I did not ask directly about 'self-censorship' as I did not want to impose any normative judgements about Cuban journalism but, rather, wanted to hear stories from the journalists' workdays.

Generally, I found participants to be quite critical both of their own role, and of the state media system of which they are part. This, however, was often limited itself to general claims, or to hypothetical examples. More experienced reporters, in particular, were hesitant to share details about personal experiences - which may be a result of a general scepticism towards foreigners having opinions on Cuban media or worries about information being misused. The younger participants shared more details and examples of how their journalistic work was restricted by the plaza sitiada mentality, and I therefore quote these interviews quite frequently. However, one may expect a degree of social desirability bias (Bryman, 2016) in this selection, as journalist participants did represent their state media outlet and, despite anonymity, probably did not want to express positions outside acceptable limits. For instance, admitting working for media outlets 
outside the state can be controversial. (This is discussed in other articles for my PhD project, of which this article is part; I nevertheless consider the discussions outside the scope of this article.)

All interviews were conducted in Spanish. The quotes appearing here were translated into English by me and verified by a proofreader. The responses from my sample are not applicable to all journalists throughout Cuba, but the interviews offer insights into some journalistic perceptions in a changing society.

\section{Applying self-censorship to protect the nation}

Journalists of all age groups have grown up in a society marked by the difficult relationship to its northern neighbour. As young reporter Jorge (personal communication, November 9th, 2016) puts it, after explaining how his family struggled to get benzathine penicillin to cure his rheumatic fever: "that sensation of being under siege, you have it in your veins because you were born under it and the country has had to live that way". In the state media there is an obligation to support the policies of the Communist Party. The three main newspapers in Cuba, Granma, Trabajadores, and Juventud Rebelde, are all official organs of the PCC or its connected organisations. That does not, however, mean that journalists are mere propaganda tools, or that they lack autonomy. What is published in the state media often depends on decisions made by the editor, who can be either more or less conservative.

Journalism education in Cuba is currently a five-year programme that all journalists working in state media go through. The curricula are quite extensive and follow many of the ideals of 'Western' journalism education, such as investigative journalism, criticism of societal malfunctions, and ethics. Coming from an extensive journalism education, the decision/willingness to selfcensor among participants is based on adaptation processes in the newsroom as well as on the journalists' own support for the Cuban socialist project and editorial policies. A young reporter, Tania, says: "There are many things we think we cannot talk about. Not because we made it up, but because there is a tradition from which we have learnt" (Tania, personal communication, November 15th, 2016).

Part of this tradition consists of relating to the PCC's changing analysis of the outside world, and particularly the relationship to the 
US. While some journalists question the usefulness of the contextdecisive editorial guidelines state media operate with, there is a general acceptance of the underlying strategic and political reasons. Journalists of all age groups consider the socialist project in Cuba to be threatened by the US. They share the sense of a fight between David and Goliath in the field of communication - one that Cuba can never win. One strategy used by journalists is to avoid sharing information in the media, rather keeping it in closed circles instead. Senior reporter Carmen says:

Generally, we are very critical at the interior. If you say four things into a microphone, they end up in Miami. They manipulate everything and people living here then believe you want to overthrow the system. [...] When we truly discuss things, they do not go through the official public channels of communication. (Carmen, personal communication, November 12th, 2016).

Discussions on what Cuban journalism should look like - or which changes are needed in the state media - can be both critical and harsh when journalists meet at the gatherings of the UPEC. However, the content of speeches made here are not to be shared with the outside world unless one is willing to take the consequences. One example is when a Cuban journalist published a speech, given at a UPEC conference by a deputy director of Granma, on his blog. The speech warned about Cuba heading towards a new economic recession and the difficulty of dealing with public unrest without the charismatic leadership of Fidel Castro. This criticism, coming from within the higher echelons of the PCC, was picked up by media outlets in Miami, causing the journalist both to lose his job as a radio reporter and to be expelled from the UPEC (Gámez Torres, 2016; Martínoticias, 2016).

\section{Blurred lines}

The limits of what can and cannot be said, and how and in which forum it should be expressed, are, however, difficult to determine. Moreover, establishing what information could be useful for the US, or may contribute to negative stories about Cuba in the Miami press, is an uncertain process. Some journalists seem more comfortable than others in filtering out appropriate information. Jorge, a young reporter, considers that if "some institution or we ourselves 
have decided we don't want to talk about this, it is always in regard to the greater good of the country". He mentions a case where a company wanted to establish itself in Cuba and create jobs, and considers that such information should not be published in the media: "If we made this public, the next thing that will happen is the US imposing a fine of millions of dollars on that company, which will bail out and do nothing in Cuba. So what do you do? You don't talk about that company" Jorge, personal communication, November 9th, 2016).

This may be something of an established norm of (self-) censorship, as proposed by Cuban scholar García Luis (2013, p. 154), on what Cuban journalists need to consider. Senior reporter Carmen considers the practice of self-censorship as more of a 'balancing' act. She describes a hypothetical example of how a crumbling building will be reported in state media, a recurrent story as most of the colonial houses of Havana are in terrible condition. She says Granma, as an official organ of the PCC, will cover the event focusing on how effective and quick the rescue team was, not that the reason for the collapse was decades of neglect: "Why? Because if Granma is critical it goes straight to the Miami Herald. In [my media outlet] we might give more information on the background, but the coverage must always be balanced so that it does not end up in the wrong hands. It should not be censored, but not so critical that it ends up in Miami" (Carmen, personal communication, November 12th, 2016).

Journalists agree to keep certain issues silent in order to avoid media outlets, particularly those in Miami, from getting information they could use 'against' Cuba. At the same time, the editorial policies that journalists must follow are at times excessively restrictive, according to some journalists. Young reporter Tania says, for instance, that she wrote a story on Cuban orphans that she was unable to publish, despite the fact that the orphanages receive substantial subsidies from the state and are in good condition: "We could not talk about it, because if we did it could be used to say that in Cuba there are a lot of orphans. There are orphans everywhere in the world, right, but if it's in Cuba..." (Tania, personal communication, November 15th, 2016).

Middle-aged reporter Ernesto had a similar experience when writing a critical theatre review. The director told him that there was no need to expose problems to the outside world, as they should be resolved and analysed internally. For these journalists, despite initially disagreeing with editors and directors, the omission of 
subjects deemed sensitive in relation to the US, encourages selfcensorship. Ernesto says: "Later, on a different occasion I wanted to write a similar piece, but I thought, "Why am I going to waste neurons writing a critique if I cannot publish it"' (Ernesto, personal communication, December 9th, 2016).

\section{The cost of hiding information}

The Cuban way of shaping society, of removing the hegemony of the world's undisputed superpower in a grassroots rebellion, and creating a society funded on ideological ideals diametrically opposed to that of the US, inspires pride and a willingness to sacrifice. For Cuban journalists, this also becomes something of a contradiction. They have to give up certain professional standards in order to fulfil the requirements of the 'revolution', and to protect the nation. When official representatives exploit their position in the name of national security and refuse to give journalists information they need on everyday issues, the perceived conflict grows, creating frustration. This practice among state functionaries is popularly called secretismo. Fariñas (cited in Garcés, 2012, p. 76) writes that the informational control of governmental institutions is killing the agility of the profession: "It would be naive to deny that Cuba is subject to an economic war, but it would also be naive to deny that a lot of the institutions hide behind this argument". García Luis (2013, p. 153) states that controlling the press because of external threats is contradictory: "Certainly, a mute, ineffective, acritical press favours the enemy more than ourselves".

Senior reporter María says institutions only distribute information to journalists if it is in their own interests. For instance, if the UN is to vote on the blockade, institutions may give information on their challenges. If journalists initiate contact, information is only obtained 'with a lot of difficulty'. The editorial policy of state media outlets also promotes the practice of secretismo, as a statement from a state functionary is needed for all stories covering issues relating to the government or official policy. Young reporter Yanet recalls a story she had wanted to write about a street in poor condition, but the person in charge refused to give an interview, so the story could not be published. She reflects: "They tell you to be critical, but you need sources that speak to you. [...] They know you are a journalist, they 
know you are from a powerful media outlet, and they will not give you information. Why? Because it will be harmful to their job, they might get fired" (Yanet, personal communication, November 11 th, 2016).

The lack of access to information due to institutional secrecy also promotes self-censorship as journalists choose less difficult subjects to cover. There is always a 'big day of history' coming up, or another institution willing to share certain information, and journalists often opt for these less controversial stories instead, young reporter Jorge explains. The shortage of information created by secretismo, censorship and self-censorship makes it difficult for journalists who want to challenge institutionalised norms because they will simply not be published. As state media often represent the opinion of the PCC, an official spokesperson will not comment on anything unconfirmed or outside the interest of the party. Rumours are therefore something state media cannot write about. Anyone spending time in Cuban streets will notice that they abound with hearsay, and non-state media outlets take advantage of the potential in this innuendo. Young reporter Tania worries about the removal from the everyday concerns of Cuban people: "[The Miami Herald] is writing about a rumour that may be a lie, but it is close to you, to your reality [...] so, what is the consequence of not mentioning it? People will look for other sources" (Tania, personal communication, November 15th, 2016).

The Cold War scenario that formed the state media is increasingly becoming outdated, and bloggers and non-state media, as well as news outlets produced abroad, challenge the news hegemony of the state media. Despite that non-state media outlets have a limited range of impact, due to the expense of access to the internet, they do influence content in state media outlets. Therefore, the silencing of negative news is neither efficient nor does it contribute towards legitimising the state media. For example, the state media do not usually cover deaths, crimes or robberies. Tania describes an incident in which a guard was stabbed by a robber. A police officer chased the robber and shot him in the foot. This was filmed by a person in a wi-fi park, who uploaded it online. It went viral. The film was picked up by the South Florida media that made a 'big deal about it', and the next day a local Cuban newspaper published a story about the robbery. Tania ponders: "That was the first time they used a story about a crime involving bloodshed in Cuba. What does this indicate? That the new means of communication are compelling the media to 
cover new content and imposing new criteria of newsworthiness" (Tania, personal communication, November 15th, 2016).

The confinement of certain topics to closed circles in Cuba is also something young reporters contest, believing that more openness will strengthen, not damage, the 'revolution'. Of the plaza sitiada mentality, young reporter Carlos says: "I am more and more convinced that it is false, that we have to discuss things publicly. Because it is worse that our readers [...] think we are satisfied with what we are doing. That is more dangerous than if they misinterpret us abroad" (Carlos, personal communication, November 17th, 2016). Changing the state media system is, however, not something any individual journalist can accomplish alone, but from time to time there are stories diverting from the normal institutionalised pattern. For instance, the editor of state newspaper Juventud Rebelde allowed a story on how secretismo hindered journalists writing about the popular state-run ice-cream parlour Coppelia (Bugallo, 2016). It is uncommon to see state officials criticised publicly. In addition, letters from readers put pressure on public institutions, and this has a ripple effect for many journalists. Jorge says: "When we ask you for information, you are a public servant, you cannot stay quiet about it, otherwise you are going to join the Coppelia list. Everybody answers, trust me, everybody" (Jorge, personal communication, November 9th, 2016).

\section{Under siege by the 'enemy'}

As noted in the literature review above, research on self-censorship in authoritarian countries tends to explain the phenomenon through journalistic considerations of punishments and rewards by the ruling party. These factors definitively come into play for Cuban journalists, but perhaps in different ways than, for instance, in Russia and China. Rewards in Cuban state journalism are seen particularly through the promotion of journalists and editors who show a true dedication to the 'revolution'. As demonstrated by the blog post where internal criticism at a UPEC meeting was exposed, there are consequences if one oversteps the limits of acceptable behaviour. It seems, however, that the individual's perception of ideological or social values, as well as the threat from the enemy, are elements of equal importance in Cuban state media journalists' self-censorship strategies. 
Journalists extensively support the national project of equal opportunity, distribution of wealth and anti-capitalism, and see these values threatened by the desire of the US to establish a liberal democracy on the island. Self-censorship on any issue that might help the enemy achieve this can, therefore, easily be justified and explained as necessary. If there is a possibility, real or imagined, that a story can damage the development of Cuba or lead to harmful coverage in Miami, journalists see justification in depriving the public of this information, or in 'balancing' coverage, thus only telling parts of the story. As Jorge puts it: 'It's for the greater good of the country'. Journalists are in a gatekeeping position, fulfilling the revolutionary goals of opposition to the subversion of Cuban values.

At the same time, journalists' ethical and professional values are threatened by such self-censorship practices. Journalists of all ages and positions desire change in the state media, wanting in particular to break up the close bonds to the Communist Party and to move further towards the interests of the people. Journalists consider that depriving the people of information, through censorship, selfcensorship or through the effects of secretismo, is against the goals of the 'revolution'. García Santamaría (2017, p. 228) pinpoints the same contradiction in her PhD dissertation on Cuban journalism. The powerful image of the US as the enemy makes participation in public rallies or other commemorative ceremonies important for journalists in order to 'reassert their revolutionary belonging'. But there is a general agreement among journalists that the threat is over-exaggerated. It is difficult to distinguish real commitment from official pressures, and these can also overlap.

Cuban state media journalists can be identified with the 'loyal-facilitator model', in both the variant that protects the status quo and those in power, and those encouraging national belonging and prestige (Mellado \& Van Dalen, 2013, p. 862). For more than half a century the state media have moved in this direction, and the younger journalists learn through socialisation how the country is best protected. As the enemy image of the US has been developed, not only is it dispositional (Ottosen, 2004) in the sense that aggression is expected, it is also well internalised in the Cuban culture and mentality (Luostarinen, 1989). It is not, therefore, easy to separate the desires of individual journalists from those of the collective, the nation. This may serve also to explain why journalists cooperate with a system that contradicts their professional ideals. 
It thus seems that journalists have incentives for opposing or changing self-censorship strategies on a theoretical or ideal level, but putting it into practice is difficult. The journalist could be punished, but a more likely and perhaps harsher consequence could be acquiring a label as an anti-patriotic or even as a friend of the enemy. This is not an uncommon tag put on non-state actors or bloggers who question the status quo (García Santamaría, 2017, p. 234). There is also some convenience for journalists in accepting the PCC's current analysis of the 'enemy' and the outside world. Blaming the 'system' for the lack of fulfilment of professional ideals may bridge the dissonance between ideals and practice, while implying that they do not have to leave their comfort zones. Skjerdal (2010, p. 113) finds the same tendency among Ethiopian journalists; they experience an individual responsibility to promote the prosperity of the nation, but also use the rigidity of the state media system to legitimate self-censorship and slacken personal ethical standards.

One might argue that Cuban journalists take control over external framing to some degree when deciding which information is suitable to present to the 'enemy'. At the same time, journalists lose control over what is said about Cuba when censoring or selfcensoring entire segments of public interest. It further leads to a delegitimisation of the state media when Cubans resort to news from the 'enemy', from Florida news outlets, in order to read stories about murders, crimes or other negative domestic news.

However, as pointed out by Tania, the growing ecosystem of media outlets in Cuba is bringing new criteria of newsworthiness into the state media. Despite the PCC's tired rhetoric about permitting media autonomy, a better-connected population forces change and younger journalists are pushing limits by partly overlooking institutional restrictions within the state media. The interviews in this study, as well as that of García Santamaría (2017, p. 233), indicate that the younger journalists are bolder and more willing to expose themselves to sanction, whereas experienced journalists are more entrenched in the Cold War rhetoric of protection against the 'enemy'. For instance, Tania mentions an interview she did with a prominent Cuban woman: "This woman spoke about a lot of things that go unsaid, uncontested, unspoken. Strong opinions, very strong, very taboo. And nothing happened. Therefore, I ask myself, is it just us? Are these philosophies of being under siege even real?" (Tania, personal communication, November 15th, 2016). 


\section{Conclusions}

The threat of a US invasion undermining the Cuban system is one of the main factors consolidating the state media as supporters of the Communist Party and the 'revolution'. That the 'Bay of Pigs' lives on in the field of communication is a functional construction for the political elites that keeps enemy images alive, thus drawing attention away from their own mistakes. For journalists, the external threat encourages various forms of self-censorship. Journalists agree to avoid covering subjects that could feed anti-Cuban interests in the US. This means that large segments of public life in Cuba are silenced by state media - for instance, news on murders, crimes or the establishment of new companies. Contrary to much literature on self-censorship in other authoritarian countries, the journalists' own support of state ideology, combined with enemy images, weighs heavier than considerations of rewards and punishment (Elbaz et al., 2017).

Journalists simultaneously consider this Cold War scenario over-exaggerated and see their professional ideals threatened by extensive self-censorship. Young journalists, in particular, worry about the delegitimisation of state media as Cubans look to 'enemy' news outlets to find information otherwise censored in Cuba. While journalists claim to want a structural change away from political bonds, censorship and self-censorship, these statements remain largely at a theoretical or idealistic level. Contributing factors may be the possibility of being branded a dissident or that it is more convenient to disclaim responsibility than to oppose the 'system'. However, non-state media outlets increasingly challenge established norms, and young journalists are more willing to expose themselves to sanction.

\section{REFERENCES}

Alonso, M. O., \& Pérez, D. O. (2016). Ideology and professional culture of journalists in Cuba. Saarbrücken: Editorial Académica Española.

Bryman A (2016). Social Research Methods. Oxford: Oxford University Press.

Bugallo, S. G. (2016). How to do a story in Coppelia? [¿Como hacer un reportaje en Coppelia?]. Retrieved from http://www.juventudre- 
belde.cu/cuba/2016-09-13/como-hacer-un-reportaje-en-coppelia/

Castro, R. (2010). Discurso pronunciado por el General de Ejército Raúl Castro Ruz. Retrieved from http://www.cuba.cu/gobierno/rauldiscursos/2010/esp/r181210e.html

Díaz-Canel, M. (2019, April 15). Twitter-post. Retrieved from: https:// twitter.com/DiazCanelB

Elbaz, S., Magal, T., Nets-Zehngut, R., \& Abutbul Selinger, G. (2017). Self-Censorship of Narratives of Political Violence in the Media. In D. Bar-Tal, R. Nets-Zehngut, \& K. Sharvit (Eds.), Self-Censorship in Contexts of Conflict: Theory and Research (pp. 119-138). Springer. https://doi.org/10.1007/978-3-319-63378-7_6

Gámez Torres, N. (2016, July 01). Subdirectora de Granma alerta sobre protestas en Cuba si vuelven "apagones". [Deputy director of Granma warns of protests in Cuba if "blackouts return] Retrieved from: http://www.elnuevoherald.com/noticias/mundo/america-latina/cuba-es/article87180612.html

Garcés, R. (2012). La prensa cubana frente al 17D: Los viejos problemas y los nuevos desafios. [The Cuban press and 17D: old problems and new challenges] Controversias y concurrencias latinoamericanas, $8(12)$.

García Luis, J. (2013). Revolution, Socialism, Journalism. Cuban press and journalists facing the 21 st century [Revolución, Socialismo, Periodismo. La prensa y los periodistas cubanos ante el siglo XXI]. Havana: Pablo de la Torriente. Retrieved from: http://etheses. whiterose. ac.uk/18999/

García Santamaría, S. (2017). The Historical Articulation of 'the People' in Revolutionary Cuba. Media Discourses of Unity in times of National Debate (1990-2012). (PhD Dissertation). University of Sheffield, Sheffield.

Granma. (2018, July 15). Discurso de Díaz-Canel en la clausura del X Congreso de la UPEC. [Speech by Díaz-Canel at the closure of the $X$ congres of UPEC] Retrieved from: http://www.granma.cu/cuba/201807-15/discurso-de-diaz-canel-en-la-clausura-del-x-congreso-de-laupec-15-07-2018-11-07-42

Guerra, L. (2012). Visions of power in Cuba: revolution, redemption, and resistance, 1959-1971 Chapell Hill: University of North Carolina Press. 
Hernández, R. (2003). Looking at Cuba: essays on culture and civil society. Gainesville, Fla: University Press of Florida.

Lee, C.-C. (1998). Press Self-Censorship and Political Transition in Hong Kong. Harvard International Journal of Press/Politics, 3(2), 55 73. https://doi.org/10.1177/1081180×98003002005

Luostarinen, H. (1989). Finnish Russophobia: The Story of an Enemy Image. Journal of Peace Research, 26(2), 123-137. https://doi. org/10.1007/978-3-319-63378-7_610.1177/002234338902600 2002.

Marrero, J. (2006). Cuban journalist congresses [Congresos de periodistas cubanos]. Havana: Pablo de la Torriente.

Marrero, J. (2003) Dos siglos de periodismo en Cuba [Two centuries of journalism in Cuba]. Havana: Pablo de la Torriente.

Martínoticias. (2016, August 03). Expulsan a periodista por reproducir palabras de subdirectora de Granma. [Journalist expelled for reporting speech of Granma deputy director] Retrieved from: https:// www.martinoticias.com/a/cuba-expulsan-trabajo-periodista-publicopalabras-karina-marron-granma/127286.html

Mellado, C., \& Van Dalen, A. (2013). Between Rethoric and Practice: Explaining the gap between role conception and performance in journalism. Journalism Studies, 15(6), 859-878 https://doi.org/10.1080/ $1461670 X .2013 .838046$

Merrett, C. (2001). A tale of two paradoxes: media censorship in South Africa, pre-liberation and post-apartheid. Critical Arts, 50.

Nohrstedt, S.-A., \& Ottosen, R. (2001). Summary and Conclusion. Globalization and the Gulf Conflict 1990-2000. In S.-A. Nohrstedt $\&$ R. Ottosen (Eds.), Journalism and the new world order. Gulf war, national news discourses and globalization (Vol. 1) (pp. 241 - 270). Gõtheborg: Nordicom.

Ottosen, R. (2004). Fiendebilder i journalistikken [Las imágenes del enemigo en el periodismo]. In B. v. d. Lippe (Ed.), Medier, politikk og samfunn [Medios, política y sociedad] (4th ed.) (pp. 217-242). Oslo: Cappelen akademisk.

PCC. (2018). Política de Comunicación Social del Estado y el Gobierno cubanos. [Social Communication Policy of the Cuban State 
and Government] Retrieved from https://www.periodismodebarrio. org/2018/12/que-dice-la-nueva-politica-de-comunicacion-cubana/

Periodismo de Barrio. (2018, December 02). ¿Qué dice la nueva política de comunicación cubana? [What does the new policy of communication in Cuba say?] Retrieved from: https://www.periodismodebarrio.org/2018/12/que-dice-la-nueva-politica-de-comunicacion-cubana/

Reporters Without Borders. (2018). Cuba, Continuing ordeal for independent media. Retrieved from https://rsf.org/en/cuba

Rivero, Y. M. (2015). Broadcasting Modernity: Cuban Commercial Television, 1950-1960. North Carolina: Duke University Press.

Siebert, F. S., Peterson, T., \& Schramm, W. (1984). Four theories of the press: the authoritarian, libertarian, social responsibility and Soviet communist concept of what the press should be and do. Urbana, III: University of Illinois Press.

Simons, G., \& Strovsky, D. (2006). Censorship in Contemporary Russian Journalism in the Age of the War Against Terrorism. European Journal of Communication, 21(2), 189-211. https://doi. org/10.1177/0267323105064045.

Skjerdal, T. S. (2010). Justifying Self-censorship: A Perspective from Ethiopia. Westminster Papers in Communication and Culture, 7(2), 98-121.

Tapsell, R. (2012). Old Tricks in a New Era: Self-Censorship in Indonesian Journalism. Asian Studies Review, 36(2), 227-245. http://doi.org /10.1080/10357823.2012.685926.

Waisbord, S. (2012). Democracy, journalism, and Latin American populism. Journalism, 14(4), 504 - 521. https://doi. org/10.1177/1464884912464178

WoJ. (2012). Worlds of Journalism Study. Master questionnaire 201214. Retrieved from: http://www.worldsofjournalism.org/research/20 12-2016-study/methodological-framework/

Xu, B. (2014). Media Censorship in China. Consil on Foreign Relations. Retrieved from: http://www.cfr.org/china/media-censorship-china/ p11515

Zandberg, E., \& Neiger, M. (2005). Between the nation and the 
profession: journalists as members of contradicting communities. Media, Culture \& Society, 27(1), 131-141. https://doi. org/10.1177/0163443705049073

Anne Natvig. She is working towards a PhD on Cuban journalism. The research is connected to the departments of Communication at both Volda University College and the University of Oslo. Her main research areas are journalism, nationalism and authoritarian societies. Publications: Natvig, Anne (2018): Cuban Journalism Students: Between Ideals and State Ideology. Journalism Education 7(1). Natvig, Anne (2019): Diverging ideals of autonomy: Non-state media in Cuba challenging a broken media monopoly. Journal of Alternative and Community Media 4(3) pp.14-30. Email: natvig@hivolda.no / annenatvig@gmail.com.

TRANSLATED BY: THE AUTHOR 